\title{
An Alternative Method for the Obtention of Ceramic Foams from Gold and Silver Tailings with High Pyrite Content
}

\author{
Cristian Salazar and Lina Uribe *
}

Citation: Salazar, C.; Uribe, L. An Alternative Method for the Obtention of Ceramic Foams from Gold and Silver Tailings with High Pyrite Content. Processes 2021, 9, 1897. https://doi.org/10.3390/pr9111897

Academic Editor: Jaroslav Kováčik

Received: 1 September 2021

Accepted: 20 October 2021

Published: 24 October 202

Publisher's Note: MDPI stays neutral with regard to jurisdictional claims in published maps and institutional affiliations.

Copyright: (C) 2021 by the authors. Licensee MDPI, Basel, Switzerland. This article is an open access article distributed under the terms and conditions of the Creative Commons Attribution (CC BY) license (https:/ / creativecommons.org/licenses/by/ $4.0 /)$.
School of Mining Engineering, University of Talca, Talca 3460000, Chile; crsalazar13@alumnos.utalca.cl

* Correspondence: luribe@utalca.cl

\begin{abstract}
Mining extraction operations generate a large number of tailings that contain different mineral phases such as quartz (principally), complex silicates, metallic elements, etc. Tailings impose a serious concern as it is possible to have acid mine drainage potential, leaching, and percolation events of heavy metals into the environment under certain conditions. The objective of this work was to evaluate the technical feasibility of producing ceramic foams from gold and silver tailings with high sulfide gangue through a previous flotation process to eliminate impurities associated to this gangue, as it can produce $\mathrm{SO}_{2}$ in the foaming process, and to analyze the effect of the sintering time and the temperature on the characteristics of foams obtained with this type of waste. The results showed that the inverse flotation reduced the presence of impurities associated to sulfides. In addition, it was possible to observe that in the absence of a foaming agent, it was possible to obtain ceramic foams with an apparent density and a mechanical strength near to $1.0 \mathrm{~g} / \mathrm{cm}^{3}$ and $0.5 \mathrm{MPa}$, respectively, when a higher sintering temperature and time were used. On the other hand, the presence of the foaming agent reduced the apparent density to $0.5 \mathrm{~g} / \mathrm{cm}^{3}$ without decreasing to a great extent the mechanical strength of ceramic foams at lower sintering temperatures.
\end{abstract}

Keywords: tailings; flotation; ceramic foams; sintering time; circular economy

\section{Introduction}

Mining extraction operations generate a large amount of tailings. About 5 to 7 billion of tons of tailings per year are disposed into the environment [1] and usually stored in tailing dams. In general, tailings contain different mineral phases such as quartz (mainly), complex silicates, metallic elements, etc. [2]. Usually, the metallic elements that can be found in tailings are iron, sulfur, copper, and zinc. The presence of those elements can generate environmental pollution [3]. For instance, gold-silver tailings usually have a large proportion of pyrite or other sulfides. The presence of those could form sulfuric acid under the combined effect of water and oxygen. The leaching of heavy metals from the tailings can be accelerated due to the formation of this acid [3]. Therefore, how to dispose tailings properly has become a matter of increasing interest in recent years.

For years, tailings have been cataloged as a material without economic value. However, in the last few years, several projects related to the potential for recovering valuable elements by reprocessing tailings have been developed. In addition, other projects that aim to transform it into useful products have been developed such as cement mortars, concrete-making materials, bricks, etc. [4-6].

In recent years, there has been a significant increase in interest in the production and use of ceramic foams. These materials are made from inorganic material comprised of glass phase, crystal phase, and a porous structure. Ceramic foams have excellent properties such as high surface area, high permeability, high chemical stability, high mechanical strength, low density, and low specific heat. These characteristics are excellent for technological applications such as thermal and acoustic insulation materials, catalyst supports, and other fields. However, the high cost of production related to high-energy consumption and the high price of raw materials limits their use to industrial applications [7]. Another 
disadvantage of the use of ceramic foams is related to the use of foaming agents that generate gases that are harmful to the environment (i.e., $\mathrm{CO}, \mathrm{CO}_{2}, \mathrm{SO}_{2}$ ), such as carbon and sulfated-based agents [7].

Several studies have shown the use of different type tailings as raw materials on the elaboration of ceramic foams, due to the high content of Si- and Al-based compounds, which are essential to promote the formation of the glass phase during the sintering process. In addition, the presence of the alkaline and alkaline earth oxides promote the liquid phase formation during the sintering process. The use of different type of tailings takes into consideration the modification of different manufacturing variables such as type of foaming agent, temperature, and sintering time as well as the mixture with other type of wastes in order to improve the characteristics of the ceramic foams [8-13]. However, in the case of gold-silver tailings, as the sulfur gangue content (mainly pyrite) is considerable, special care should be taken, as $\mathrm{SO}_{2}$ can be produced in the foaming process, which has lower thermal conductivity than $\mathrm{CO}_{2}$ but requires more control, since it is known to be harmful [7]. Therefore, in order to consider gold-silver tailings for the production of ceramic foams, a previous process of elimination of impurities such as high sulfur gangue should be implemented.

The objective of this work is to evaluate the technical feasibility of producing ceramic foams from gold and silver tailings with high sulfur gangue considering the study of efficiency of the flotation process to eliminate impurities associated to iron and sulfur and the analysis of the effect of the sintering time and the temperature on the characteristics of foams obtained with this type of waste.

\section{Materials and Methods}

The process of manufacturing ceramic foams from gold-silver tailings with high pyrite content considered three main stages, as it is shown in Figure 1: gold-silver tailing samples characterization, concentration of silicates through a froth flotation process, and the elaboration and sintering of foams at different sintering times and temperatures.

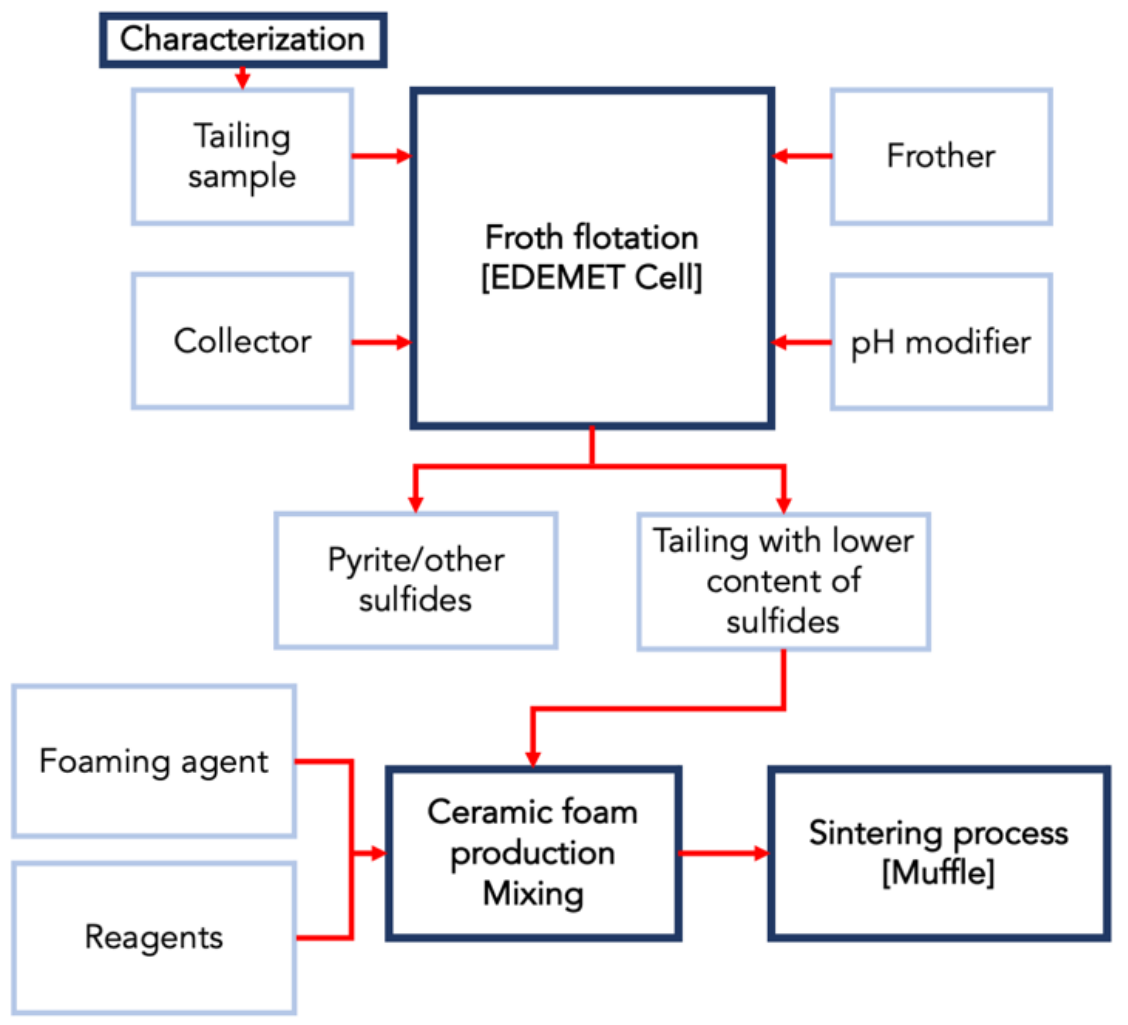

Figure 1. Process of manufacturing of ceramic foams. 


\subsection{Equipment}

For the production of the ceramic foams, the following equipment was used: RoTap and sieves (Tyler RX-29-19) to carry out the classification of the tailings prior to the concentration, with sizes between -150 and +45 microns; a Boeco OSD-20 propeller agitator for preparing the feed pulp for the flotation concentration process and preparing the foaming quartz mixtures; a Fritsch planetary mill for grinding reagents used in the production of ceramic foams; a flotation cell, EDEMET filter, and drying oven to concentrate the raw materials of interest, remove the water, and dry the recovered raw materials, respectively; and a Muffle Biobase Mf10-12G to perform the sintering process.

The mineralogy of gold-silver tailings was determined by Automated Mineralogy on TESCAN VEGA equipped with the software TIMA Mineral Analyzer. In addition, an X-Ray Fluorescence analyzer (XRF) Niton XL3t, Thermo Fisher Scientific was used to determine the chemical composition of the gold-silver tailings. The particle size analysis of the gold-silver tailing samples was made by using a Fritsch Analysette 22 MicroTec Plus equipment. The density of foams was performed using a $50 \mathrm{~mL}$ Pycnometer, and a CBR loading press 34-T0102/A was used to determine the mechanical strength. Finally, the identification and quantification of crystalline phases was determined by using a Rigaku Miniflex 600 X-Ray diffraction analyzer (XRD), using the High Score Plus 3.0 software and a bank of standards assigned to Crystallography Open Database (COD).

\subsection{Samples of Gold-Silver Tailings}

Representative gold-silver tailing samples were collected from the "Chépica Mine" located at the Maule Region in Chile. The samples were dried, homogenized, and classified in sizes between -150 and +45 using a Ro-Tap and Sieves $-100 /+325$ Tyler. The moisture was determined by mass difference by drying the samples at $110^{\circ} \mathrm{C}$ in an oven for $24 \mathrm{~h}$. Then, particle analysis was performed using the particle size analyzer (Fritsch Analysette 22 Micro Tec Plus equipment), and the density was determined by pycnometer.

\subsection{Reagents}

The following reagents supplied by Solvay ${ }^{\circledR}$ were used in the froth flotation process: Potassium amyl xanthate (PAX) at a concentration of $60 \mathrm{~g} /$ ton as a metal sulfide collector reagent, Methyl-Isobutyl-Carbinol (MIBC) at $20 \mathrm{~g} /$ ton as a frother, and hydrochloric acid ( $1 \mathrm{~mL}$ of $0.6 \%$ solution) and lime ( $2 \mathrm{~mL} 20 \%$ solution) as $\mathrm{pH}$ modifiers and supplied by MERCK $^{\circledR}$ and Química universal ${ }^{\circledR}$, respectively.

Furthermore, for the production of the ceramic foams, sodium carbonate $\left(\mathrm{Na}_{2} \mathrm{CO}_{3}\right)$ supplied by MERCK ${ }^{\circledR}$ and lime $(\mathrm{CaO})$ were employed. Both reagents were used as fluxes and lime was used as the foaming facilitator. Finally, sodium silicate $\left(\mathrm{Na}_{2} \mathrm{SiO}_{3}\right)$ supplied by Winkler ${ }^{\circledR}$ was used as a foaming agent. It is important to note that both sodium carbonate and sodium silicate required a prior grinding process for $1 \mathrm{~h}$ to achieve a $\mathrm{d}_{50}$ particle size of less than 100 microns.

\subsection{Preparation of Raw Materials from Tailings}

Bearing in mind that the gold-silver tailings had a high concentration of iron and sulfur associated with the pyrite ore, a process of concentration of silicates and removal of impurities was carried out through the process of reverse flotation, which consisted of floating the impurities, by adhesion of the same air bubbles and collecting the silicates in the sedimented material in the flotation cell. Figure 2 shows the scheme of reverse flotation process carried out.

To achieve this, the flotation process considered the following steps: conditioning, flotation, filtration, and drying:

The conditioning stage was carried out in a $1.5 \mathrm{~L}$ cell by adding a pulp containing $600 \mathrm{~g}$ of mineral and $1200 \mathrm{~g}$ of water, forming $33 \%$ of solids by weight, keeping the $\mathrm{pH}$ value at desired $\mathrm{pH}$. Once this was achieved, flotation reagents (collector and frother) were added, and the pulp was mixed for a period of $5 \mathrm{~min}$. 


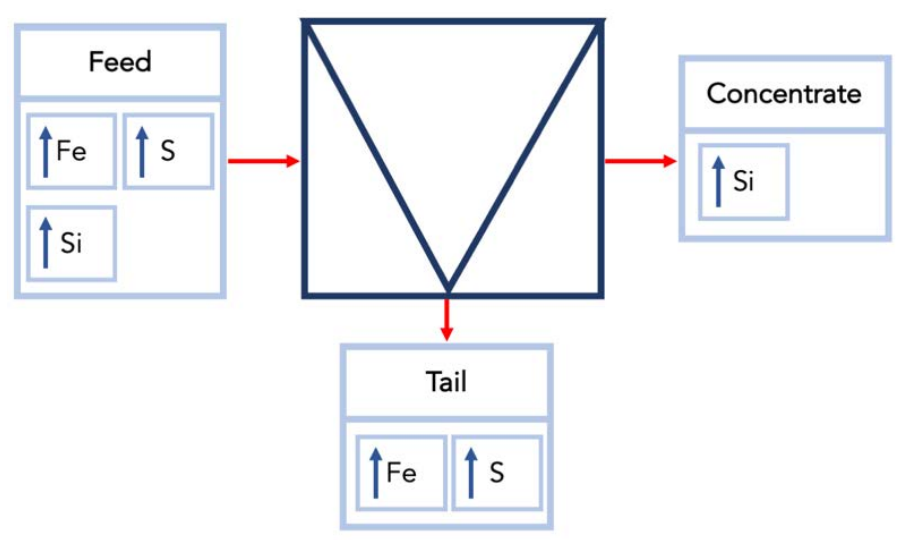

Figure 2. Scheme of reverse flotation process carried out in this study.

Subsequently, the flotation stage was continued, which lasted $15 \mathrm{~min}$ and consisted of giving way to the injection of air into the cell, which generated the separation of the materials of interest. Once this time was completed, the process of filtration and drying of the concentrate and tail was carried out in a Edemet pressure filter and a drying oven for approximately $24 \mathrm{~h}$ at a temperature of $100{ }^{\circ} \mathrm{C}$. Later, the corresponding analysis was carried out using XRF to determine the content of $\mathrm{Fe}, \mathrm{S}$, and $\mathrm{Si}$ in each sample and finally to calculate the metallurgical indexes.

It is important to note that the operational conditions in this process corresponded to a stirring speed of $800 \mathrm{rpm}$, a pH of 4 , and an airflow of $5 \mathrm{~L} / \mathrm{min}$. Additionally, as flotation reagents, PAX at $60 \mathrm{~g} /$ ton and MIBC at $20 \mathrm{~g} /$ ton were used as the collector and frother, respectively, and $\mathrm{HCl}$ and calcium oxide were used as $\mathrm{pH}$ modifiers.

\subsection{Ceramic Foams Elaboration Processes}

The silicate-rich flotation concentrate, once dry, is mixed with sodium carbonate, lime, and sodium silicate following a process of mechanical stirring with the solid materials for $5 \mathrm{~min}$ and for another $7 \mathrm{~min}$ with the addition of water. Once the mixing process of the components was completed, the obtained mixture was poured into clay specimens of $4.5 \mathrm{~cm}$ diameter, and the compaction was carried out by hydraulic pressing ( 4 ton) for $3 \mathrm{~min}$.

To evaluate the effect of the operational conditions on the elaboration of ceramic foams, the temperature and sintering time conditions shown in Table 1 were evaluated. The table presents the set of samples elaborated in triplicate to evaluate the effect of temperature between 850 and $880^{\circ} \mathrm{C}$ maintaining a fixed time of $45 \mathrm{~min}$, and the influence of sintering time at a fixed temperature of $860^{\circ} \mathrm{C}$. It is important to note that the conditions used in this study were established based on the results obtained in $[13,14]$.

\subsection{Calculation and Methods of Analysis Used}

Metallurgical Indexes to Calculate the Efficiency in the Concentration Process by Inverse Flotation

The grade of $\mathrm{Si}, \mathrm{Fe}$, and $\mathrm{S}$ in the concentrate and the tail were determined; these data allowed calculating the recovery and enrichment ratio. Table 2 shows the formulas used to calculate these indexes.

The different samples considered percentages of sodium silicate as the foaming agent of $12 \%$ and $16 \%$ with fixed contents of lime (5.58\%), sodium carbonate $(17.52 \%)$, and water $(2.6 \%)$. On the other hand, depending on the percentage of foaming agent used, the addition of raw material from tailings was adjusted to $62.3 \%$ or $58.3 \%$. In addition, samples in the absence of foaming agent (sodium silicate) at each of the temperatures and times studied were considered. 
Table 1. Experimental test of samples elaborated from Chépica tailing and sodium silicate for the study of the influence of the sintering time.

\begin{tabular}{|c|c|c|c|c|c|c|c|c|c|}
\hline Sample & $\begin{array}{l}\text { Time } \\
\text { min }\end{array}$ & $\begin{array}{c}\mathrm{T} \\
{ }^{\circ} \mathrm{C}\end{array}$ & $\begin{array}{c}\text { Foaming } \\
\%\end{array}$ & $\begin{array}{c}\text { Tailing } \\
\%\end{array}$ & Sample & $\begin{array}{c}\mathrm{T} \\
{ }^{\circ} \mathrm{C}\end{array}$ & $\begin{array}{l}\text { Time } \\
\text { min }\end{array}$ & $\begin{array}{c}\text { Foaming } \\
\%\end{array}$ & $\begin{array}{c}\text { Tailing } \\
\quad \%\end{array}$ \\
\hline CP-SS-01 & \multirow{8}{*}{45} & 850 & 12 & 62.3 & CP-SS-09 & \multirow{8}{*}{860} & 30 & 12 & 62.3 \\
\hline CP-SS-02 & & 850 & 16 & 58.3 & CP-SS-10 & & 30 & 16 & 58.3 \\
\hline CP-SS-03 & & 860 & 12 & 62.3 & CP-SS-11 & & 35 & 12 & 62.3 \\
\hline CP-SS-04 & & 860 & 16 & 58.3 & CP-SS-12 & & 35 & 16 & 58.3 \\
\hline CP-SS-05 & & 870 & 12 & 62.3 & CP-SS-13 & & 40 & 12 & 62.3 \\
\hline CP-SS-06 & & 870 & 16 & 58.3 & CP-SS-14 & & 40 & 16 & 58.3 \\
\hline CP-SS-07 & & 880 & 12 & 62.3 & & & & & 62.3 \\
\hline CP-SS-08 & & 880 & 16 & 58.3 & & & & & 58.3 \\
\hline \multirow{4}{*}{ None } & \multirow{4}{*}{45} & 850 & \multirow{4}{*}{0} & \multirow{4}{*}{74.3} & \multirow{4}{*}{ None } & \multirow{4}{*}{860} & 30 & & \multirow{4}{*}{74.3} \\
\hline & & 860 & & & & & 35 & & \\
\hline & & 870 & & & & & 40 & & \\
\hline & & 880 & & & & & 45 & & \\
\hline
\end{tabular}

Table 2. Formulas used to calculate metallurgical indexes.

\begin{tabular}{|c|c|c|c|}
\hline Metallurgical Performance & Formula & & Nomenclature \\
\hline Recovery, \% & $R=\frac{C c}{A a}$ & (1) & $\begin{array}{l}\text { C and } \mathrm{A} \text { are the masses of concentrate and feed, respectively. } \\
\mathrm{c} \text { and a are the grades of the species of interest in the concentrate } \\
\text { and in the feed, respectively. }\end{array}$ \\
\hline Enrichment ratio & $R e=\frac{c}{a}$ & $(2)$ & $\begin{array}{c}\text { c and a are the grades of the species of interest in the concentrate } \\
\text { and in the feed, respectively. }\end{array}$ \\
\hline
\end{tabular}

\subsection{Ceramic Foams Characterization}

The characterization of the ceramic foams was made according to Table 3 . The apparent density $\left(\rho_{a p p}\right)$ is calculated through the weight $\left(W_{c}\right)$ and volume $\left(V_{c}\right)$ of a cubic piece of the solid ceramic foam (3). The real density $\left(\rho_{r}\right)$, was calculated using a pycnometer, pulverizing the cubic piece of foam to perform the measurement (4). To estimate the mean pore size of the foamed materials, $\left(D_{p}\right)$, the image processing and analysis software ImageJ was used, maintaining the same methodology described in $[13,14]$ and then the $D_{p}$ was calculate according to Equation (7). Finally, the mechanical strength was estimated in $\mathrm{MPa}$ using a CBR loading press $(0.21 \mathrm{~mm} / \mathrm{s})$.

Table 3. Equations used for the characterization of ceramic foams.

\begin{tabular}{|c|c|c|c|}
\hline $\begin{array}{l}\text { Characterization of } \\
\text { Ceramic Foams }\end{array}$ & Formula & & Nomenclature \\
\hline Apparent density, $\left(\rho_{\text {app }}\right)$ & $\rho_{a p p}=\frac{W_{c}}{V_{c}}$ & (3) & $\begin{array}{c}\text { where } W_{c} \text { is the weight and } V_{c} \text { is the volume of a cubic } \\
\text { piece of the solid ceramic foam }\end{array}$ \\
\hline Real density $\left(\rho_{r}\right)$ & $\rho_{r}=\frac{W_{p p}-W_{e p}}{\left(W_{p w}-W_{e p}\right)-\left(W_{p p w}-W_{p p}\right)}$ & $(4)$ & $\begin{array}{c}\text { where } W_{e p} \text { is the weight of the empty pycnometer, } \\
W_{p p} \text { is the weight of the pycnometer plus powder, } \\
W_{p w} \text { is the weight of the pycnometer plus water, } \\
\text { and } W_{p p w} \text { is the weight of the pycnometer, powder, } \\
\text { and water }\end{array}$ \\
\hline Porosity $(\varphi)$ & $\varphi=\left(1-\frac{\rho_{a p p}}{\rho_{r}}\right) \cdot 10$ & (5) & $\begin{array}{l}\text { where } \rho_{a p p} \text { is the apparent density and } \rho_{r} \text { is the } \\
\text { real density }\end{array}$ \\
\hline Volumetric expansion $\left(\mathrm{V}_{\mathrm{e}}\right)$ & $V_{e}=\frac{V_{f}-V_{i}}{V_{i}} \cdot 100$ & (6) & $\begin{array}{l}\text { where } V_{i} \text { is the volume of the compacted mixture, } \\
\text { and } V_{f} \text { is the volume of the foamed material }\end{array}$ \\
\hline Mean pore size $\left(D_{p}\right)$ & $D_{p}=2 \cdot \sqrt{\frac{A_{p}}{\pi}}$ & (7) & where $A_{p}$ is the mean pore size in $\mathrm{mm}^{2}$ \\
\hline
\end{tabular}




\section{Results}

\subsection{Gold-Silver Tailings Characterization}

Figure 3 presents the particle size distribution of the gold-silver tailings sample used to produce the foams, in which it is observed that the samples used have an approximate $\mathrm{d}_{80}$ of 78 microns and a $\mathrm{d}_{50}$ of about 40 microns and additionally, a density of $2.6 \mathrm{~g} / \mathrm{cm}^{3}$.

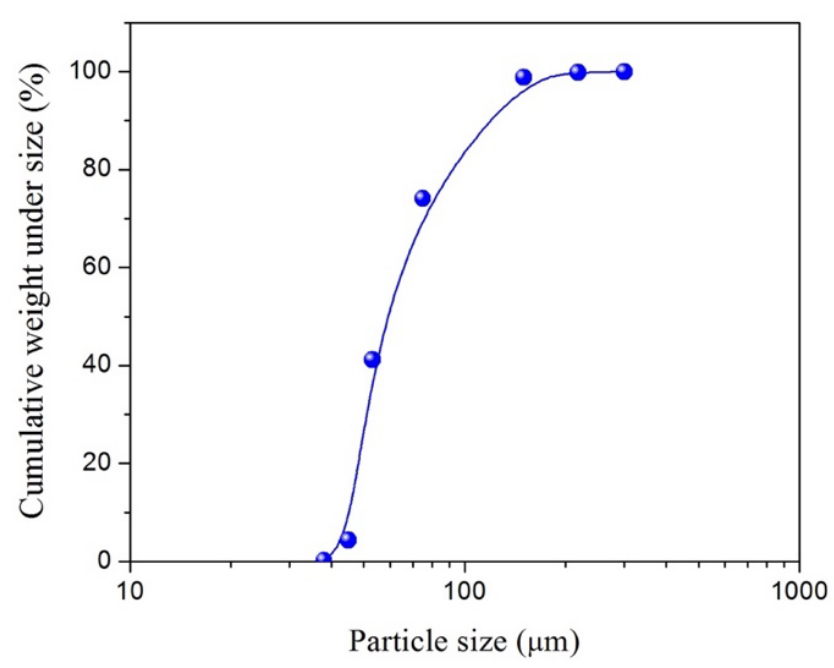

Figure 3. Particle size analysis of the gold-silver tailing sample.

Tables 4 and 5 present the elemental composition and the analysis of the mineral phases present in the gold-silver tailing sample performed by automated mineralogy on TESCAN and X-ray fluorescence (XRF), respectively. It is possible to note that the major concentration of $\mathrm{SiO}_{2}$ comes from quartz (58.06\%) and other silicates. In addition, a minor concentration iron oxide, $\mathrm{Fe}_{2} \mathrm{O}_{3}$, was found, which is associated mainly to pyrite (34.57\%). On the other hand, alkali/alkaline earth metal oxides were found as secondary and minor constituent elements: $\mathrm{K}_{2} \mathrm{O}$ and $\mathrm{CaO}$, which are present in phases such as muscovite, biotite, $\mathrm{K}$-feldspar, epidote, andesite, and anorthite. It is worth pointing out that this type of tailing has a high pyrite content, showing the necessity of a mineral concentration process through flotation, which allows removing it and enriching with silicates the raw material to be used to make the ceramic foams.

Table 4. Elemental composition by XRF of the gold-silver tailing sample.

\begin{tabular}{cccccccccccc}
\hline Constituents & $\mathrm{SiO}_{2}$ & $\mathrm{Al}_{\mathbf{2}} \mathrm{O}_{\mathbf{3}}$ & $\mathbf{F e}_{\mathbf{2}} \mathrm{O}_{\mathbf{3}}$ & $\mathrm{CaO}$ & $\mathbf{S O}_{3}$ & $\mathbf{K}_{\mathbf{2}} \mathrm{O}$ & $\mathbf{M n O}_{2}$ & $\mathrm{TiO}_{2}$ & $\mathbf{Z n}$ & $\mathbf{C u}$ & $\mathbf{P b}$ \\
\hline$\%$ & 58.06 & 2.91 & 35.04 & 0.19 & 37.57 & 1.35 & 0.06 & 0.73 & 0.73 & 0.17 & 0.54 \\
\hline
\end{tabular}

\subsection{Effect of Silicates Concentration and Elimination of Impurities through Flotation}

Table 6 shows the concentrate (C) and tail (T) in grams obtained after the flotation process and the $\mathrm{Si} \%, \mathrm{Fe} \%$, and S \% grades in the feed (f), concentrate (c), and tail (t) obtained by FRX, and Figure 4 shows a comparison between the grades of the elements silica $(\mathrm{Si})$, iron $(\mathrm{Fe})$, and sulfur $(\mathrm{S})$ of the tailings material prior to the reverse flotation process (feeding) and the two currents obtained at the end of the process, the silica-rich current (concentrated) and the impurity-rich current (tail). From Figure 4A, it is possible to observe that there is a slight increase in the concentration of silicates in the concentrate compared to the feeding. However, regarding the main impurities, it is possible to observe that in the case of iron (Figure $4 \mathrm{~B}$ ), there is a decrease of $8 \%$ in the concentrate and an increase of $16 \%$ in the tail, and for sulfur (Figure $4 \mathrm{C}$ ), there is a lower presence of this element in the concentrate, corresponding to $0.75 \%$. Meanwhile, a greater presence of this in the tail is observed, which corresponded to $20 \%$. 
Table 5. Mineralogical composition of the tailing sample by automated mineralogy on TESCAN.

\begin{tabular}{|c|c|c|}
\hline Mineral Phase & Molecular Formula & Percentage $(\%)$ \\
\hline Quartz & $\mathrm{SiO}_{2}$ & 55.06 \\
\hline Pyrite & $\mathrm{FeS}_{2}$ & 34.57 \\
\hline Muscovite/Illite & $\mathrm{KAl}_{2}(\mathrm{AlSi})_{4} \mathrm{O}_{10}(\mathrm{OH}, \mathrm{F})_{2}$ & 2.60 \\
\hline Chlorite & $(\mathrm{Mg}, \mathrm{Fe})_{5} \mathrm{Al}\left(\mathrm{Si}_{3} \mathrm{Al}\right) \mathrm{O}_{10}(\mathrm{OH})_{8}$ & 2.39 \\
\hline K-Feldspar & $\mathrm{KAlSi}_{3} \mathrm{O}_{8}$ & 2.77 \\
\hline Biotite & $\mathrm{K}(\mathrm{Mg}, \mathrm{Fe})_{3} \mathrm{AlSi}_{3} \mathrm{O}_{10}(\mathrm{OH}, \mathrm{F})_{2}$ & 0.53 \\
\hline Sphalerite & $(\mathrm{Zn}, \mathrm{Fe}) \mathrm{S}$ & 0.76 \\
\hline Hematite/Magnetite & $\mathrm{Fe}_{2} \mathrm{O}_{3}$ & 0.03 \\
\hline Tourmaline & $\underset{*}{\mathrm{AD}_{3} \mathrm{Al}_{6}\left(\mathrm{BO}_{3}\right)_{3}\left(\mathrm{Si}_{6} \mathrm{O}_{18}\right)(\mathrm{OH}, \mathrm{F})}$ & 0.10 \\
\hline Epidote & $\mathrm{Ca}_{2} \mathrm{FeAl}_{2}\left(\mathrm{Si}_{2} \mathrm{O}_{7}\right)\left(\mathrm{SiO}_{4}\right) \mathrm{O}(\mathrm{OH})$ & 0.03 \\
\hline Oxides $(\mathrm{Fe}, \mathrm{Cu})$ & $(\mathrm{Cu}, \mathrm{Fe}) \mathrm{O}$ & 0.10 \\
\hline Amphibole & $\mathrm{AB}_{2} \mathrm{Y}_{5}(\mathrm{Al}, \mathrm{Si})_{8} \mathrm{O}_{22}(\mathrm{OH}, \mathrm{F}, \mathrm{Cl})_{2}$ * & 0.01 \\
\hline Galena & $\mathrm{PbS}$ & 0.52 \\
\hline Albite & $\mathrm{NaAlSi}_{3} \mathrm{O}_{8}$ & 0.01 \\
\hline Andesite & $(\mathrm{Na}, \mathrm{Ca})(\mathrm{Si}, \mathrm{Al})_{4} \mathrm{O}_{8}$ & 0.04 \\
\hline Chalcopyrite & $\mathrm{CuFeS}_{2}$ & 0.296 \\
\hline Siderite & $\mathrm{FeCO}_{3}$ & 0.01 \\
\hline Anorthite & $\mathrm{CaAl}_{2} \mathrm{Si}_{2} \mathrm{O}_{8}$ & 0.015 \\
\hline Others & - & 0.17 \\
\hline Total & - & 100 \\
\hline
\end{tabular}

${ }^{\text {}} \mathbf{A}=\mathrm{Ca}, \mathrm{Na}, \mathrm{K}, \mathrm{Pb} ; \mathbf{B}=\mathrm{Ca}, \mathrm{Fe}, \mathrm{Mg}, \mathrm{Mn}, \mathrm{Li}, \mathrm{Na} ; \mathbf{D}$ = Al, Fe, Li, Mg, Mn, Ti; Y = Al, Cr, Fe, Mg, Mn, Ti.

Table 6. Concentrate $(\mathrm{C})$ and tail $(\mathrm{T})$ in grams obtained after flotation process and $\mathrm{Si} \%, \mathrm{Fe} \%$, and $\mathrm{S}$ $\%$ grades in the feed (f), concentrate (c), and tail (t) obtained by FRX.

\begin{tabular}{ccccccccccc}
\hline & Si, $\%$ & & \multicolumn{3}{c}{ Fe, \% } & & \multicolumn{2}{c}{ S, \% } & \multicolumn{3}{c}{ Quantity, g } \\
\hline $\mathbf{f}$ & $\mathbf{c}$ & $\mathbf{t}$ & $\mathbf{f}$ & $\mathbf{c}$ & $\mathbf{t}$ & $\mathbf{f}$ & $\mathbf{c}$ & $\mathbf{t}$ & $\mathbf{C}$ & $\mathbf{T}$ \\
\hline 28.16 & 33.02 & 13.52 & 10.13 & 2.23 & 28.12 & 12.16 & 1.40 & 31.19 & 238.2 & 348.3 \\
\hline
\end{tabular}

A.

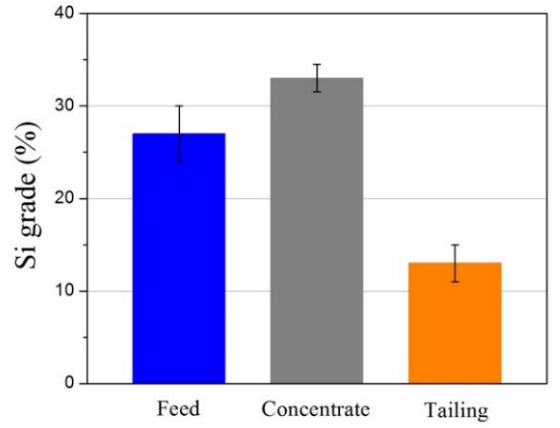

B.

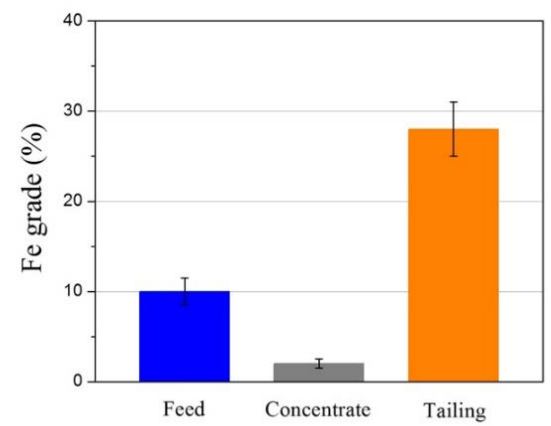

C.

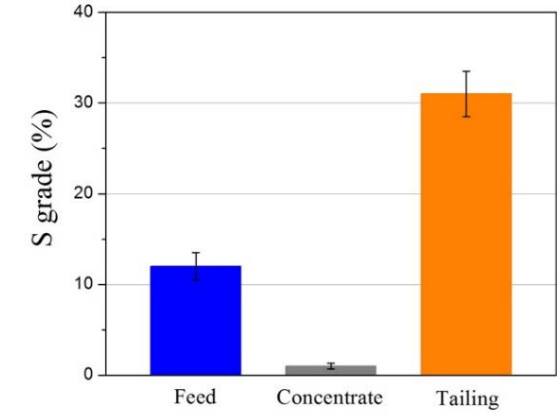

Figure 4. Comparative plot of the grades of $\mathrm{Si}(\mathbf{A}), \mathrm{Fe}(\mathbf{B})$, and $\mathrm{S}(\mathbf{C})$ present in the different stages of the flotation process. 
On the other hand, Figures 5 and 6 show the recovery and enrichment ratio of $\mathrm{Si}, \mathrm{Fe}$, and $\mathrm{S}$ obtained from the elements of interest processed in flotation, in the two currents obtained, corresponding to the concentrate and tail. From the figures, it is possible to observe that the reverse flotation process achieved a recovery of silicates of $77 \%$ in the concentrate and in the case of iron and sulfur a recovery of $89 \%$ and $96.5 \%$ in the tail. In addition, it was observed that there was a greater enrichment ratio of $\mathrm{Fe}$ and $\mathrm{S}$ in the tail. The above shows that the process of reverse flotation succeeded in removing the main impurities, which were concentrated in the tail and thus succeeded in generating a raw material rich in silicates, which will be used for the production of ceramic foams.

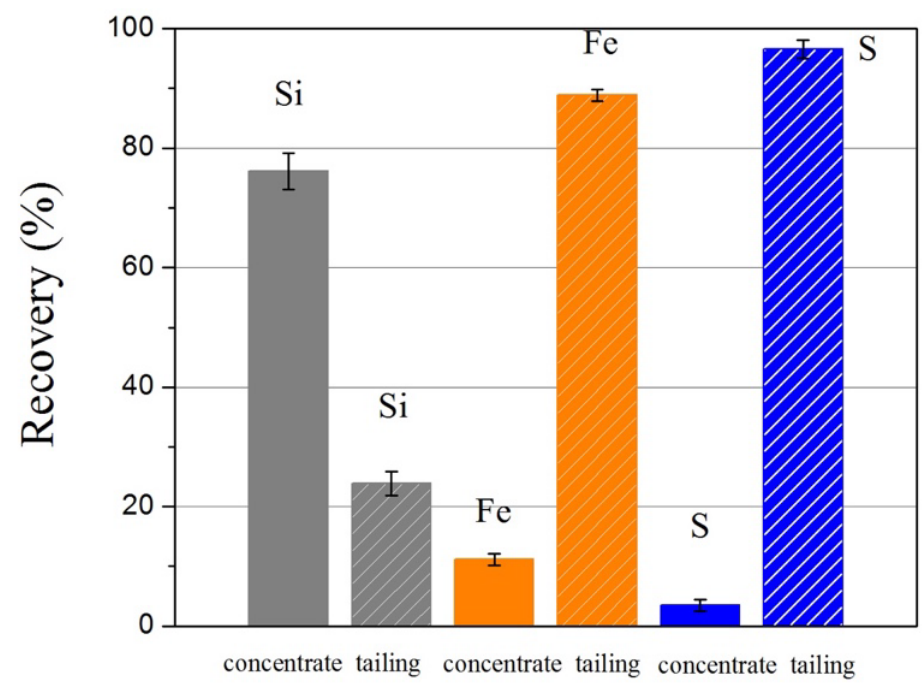

Figure 5. Recovery of $\mathrm{Si}, \mathrm{Fe}$, and $\mathrm{S}$ for the concentrated flotation samples.

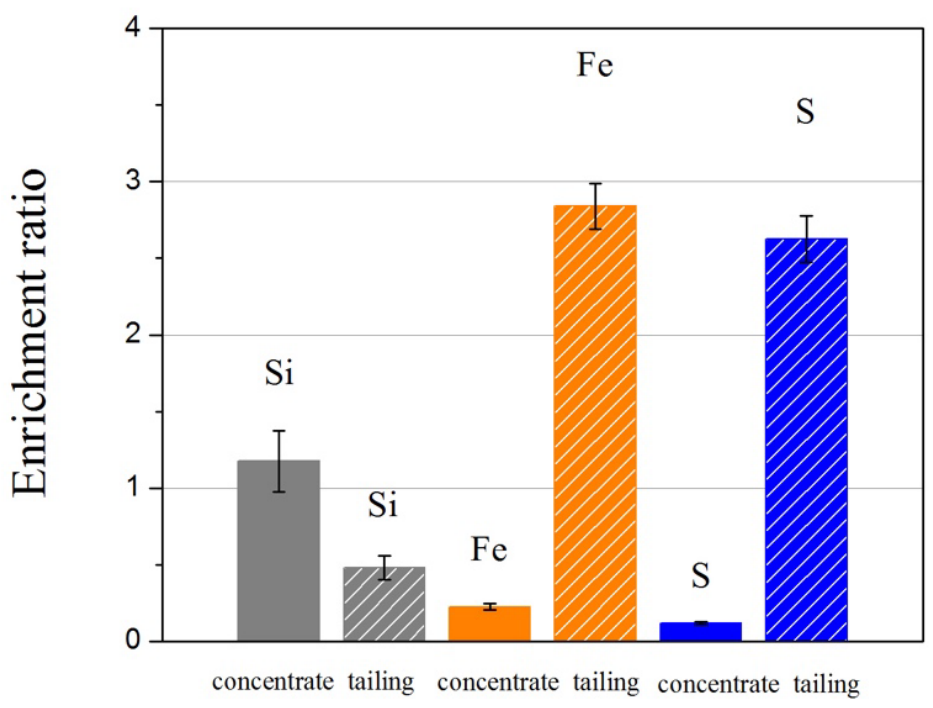

Figure 6. Enrichment ratio of $\mathrm{Si}, \mathrm{Fe}$, and $\mathrm{S}$ for the concentrated flotation samples.

\subsection{Effect of Sintering Time and Temperature on Foams Obtained in the Absence of Foaming Agent}

Figure 7 shows the cross-sections of foams produced in the absence of foaming agent at different sintering times and temperatures, maintaining a fixed temperature of $860{ }^{\circ} \mathrm{C}$ and a time of $45 \mathrm{~min}$, respectively. In the table, it is possible to observe that there was a great development of the porosity and pore size as the sintering time and sintering temperature increased, this effect being more relevant as a function of temperature. This led to the generation of ceramic foams with a minimum apparent density of $1.0 \mathrm{~g} / \mathrm{cm}^{3}$, 
a maximum porosity development of $60 \%$, and an average pore size of less than $1 \mathrm{~mm}$, as can be observed in Table 7 .

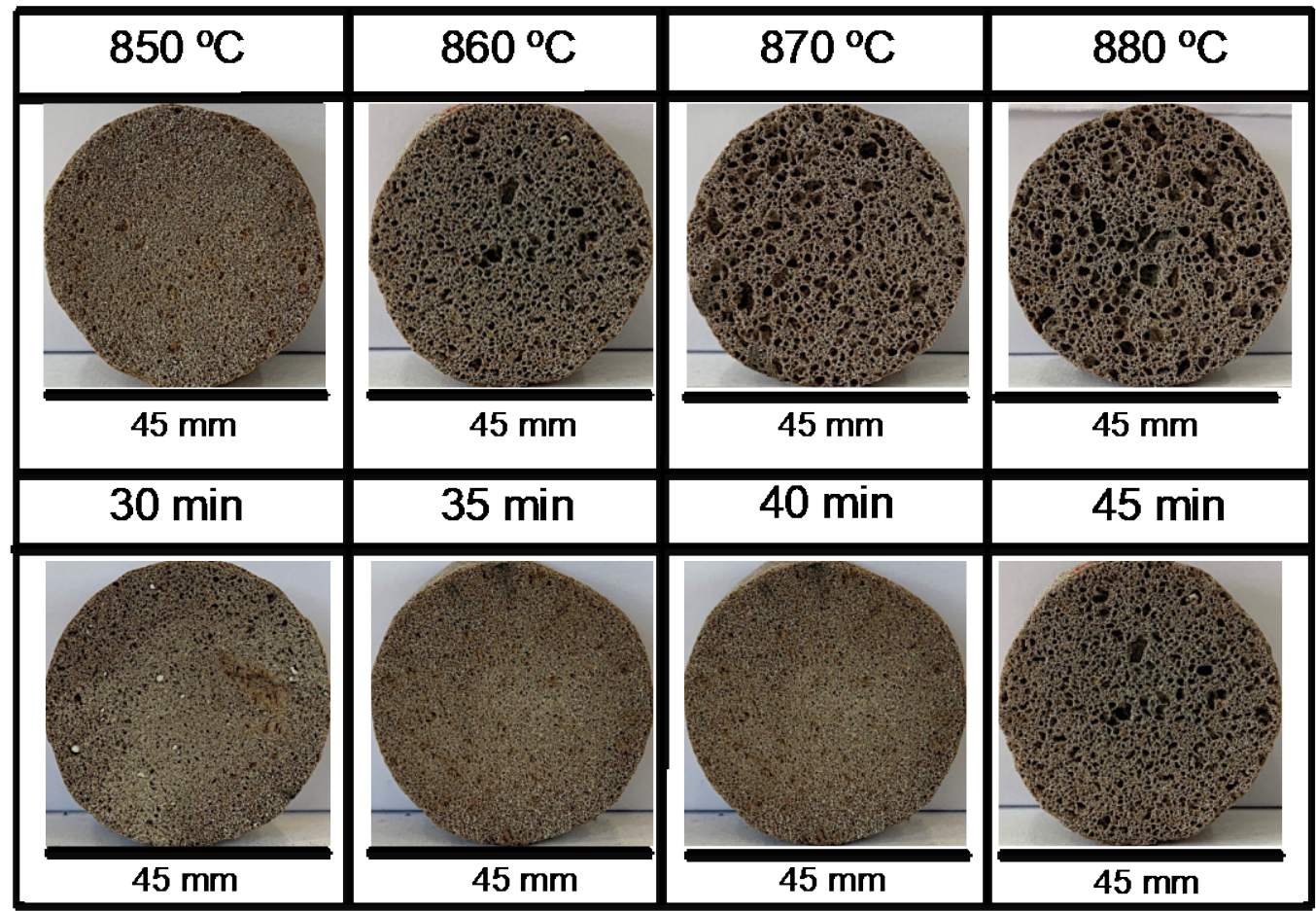

Figure 7. Cross-sectional cuts of ceramic foams produced in the absence of foaming agent and at different sintering times and temperatures.

Table 7. Characteristics of the obtained foams in the absence of sodium silicate foaming agent.

\begin{tabular}{ccccccccc}
\hline & \multicolumn{3}{c}{ Sintering Temperature, ${ }^{\circ} \mathbf{C}$} & \multicolumn{3}{c}{ Sintering Time, min } \\
\cline { 2 - 8 } & $\mathbf{8 5 0}$ & $\mathbf{8 6 0}$ & $\mathbf{8 7 0}$ & $\mathbf{8 8 0}$ & $\mathbf{3 0}$ & $\mathbf{3 5}$ & $\mathbf{4 0}$ & $\mathbf{4 5}$ \\
\hline $\begin{array}{c}\text { Real density }\left(\rho_{\mathrm{r}}\right) \\
\mathrm{g} / \mathrm{cm}^{3}\end{array}$ & 1.54 & 1.32 & 1.18 & 1.02 & 1.50 & 1.41 & 1.25 & 1.32 \\
\hline $\begin{array}{c}\text { Porosity }(\varphi) \\
\%\end{array}$ & 33.56 & 48.22 & 54.50 & 59.77 & 38.95 & 42.41 & 50.16 & 48.22 \\
\hline $\begin{array}{c}\text { Mean pore size }\left(D_{p}\right) \\
\text { mm }\end{array}$ & 0.43 & 0.50 & 0.66 & 0.67 & 0.39 & 0.41 & 0.45 & 0.50 \\
\hline $\begin{array}{c}\text { Mechanical strength } \\
\mathrm{MPa}\end{array}$ & 2.50 & 1.63 & 1.38 & 0.53 & 2.73 & 1.16 & 1.27 & 1.63 \\
\hline
\end{tabular}

\subsection{Effect of Sintering Time on the Characteristics of the Foams}

Figure $8 \mathrm{~A}, \mathrm{~B}$ show the effect of the change in sintering time on the apparent density and the mechanical strength of foams obtained at a fixed temperature of $860^{\circ} \mathrm{C}$. In the figure, it can be observed that the apparent density was between 0.4 and $0.62 \mathrm{ton} / \mathrm{m}^{3}$, being the lowest density obtained at a higher concentration of foaming agent and a maximum and minimum sintering time. When analyzing in parallel the mechanical strength of sintered samples at different sintering times (Figure 8B), it is possible to note that the mechanical strength was between 0.2 and $0.4 \mathrm{MPa}$. The highest resistance was found at a time of $45 \mathrm{~min}$, independent of the percentage of foaming agent used. 
A.

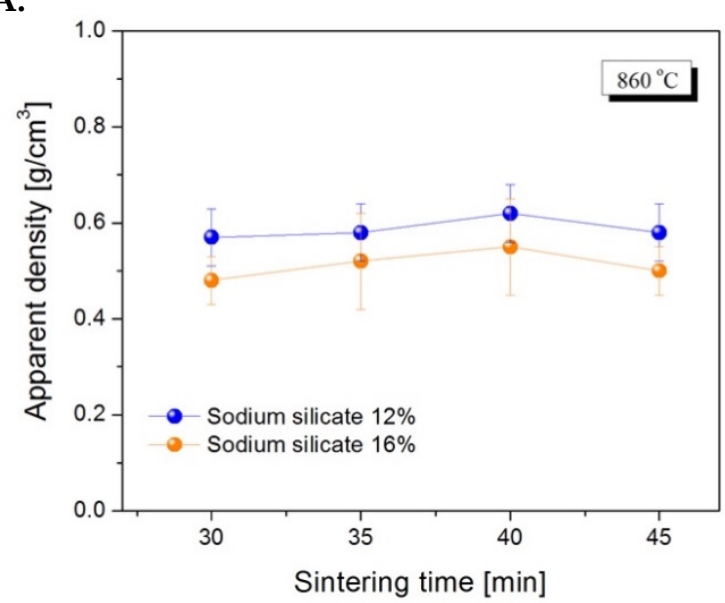

C.

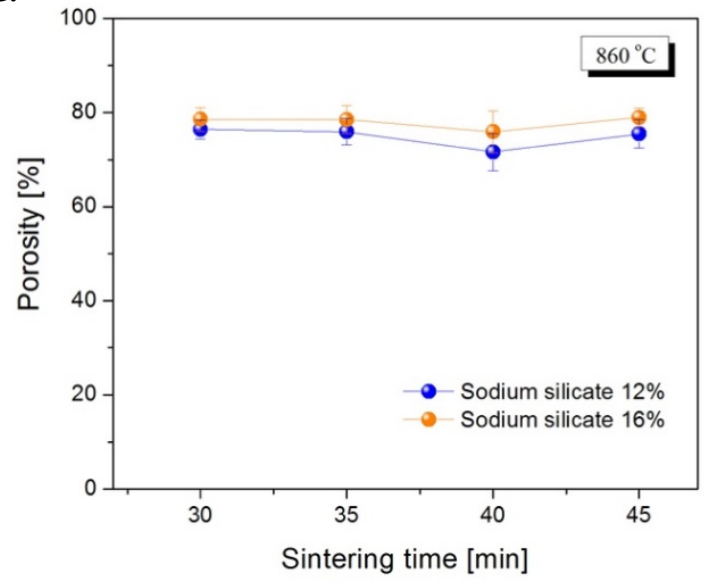

B.

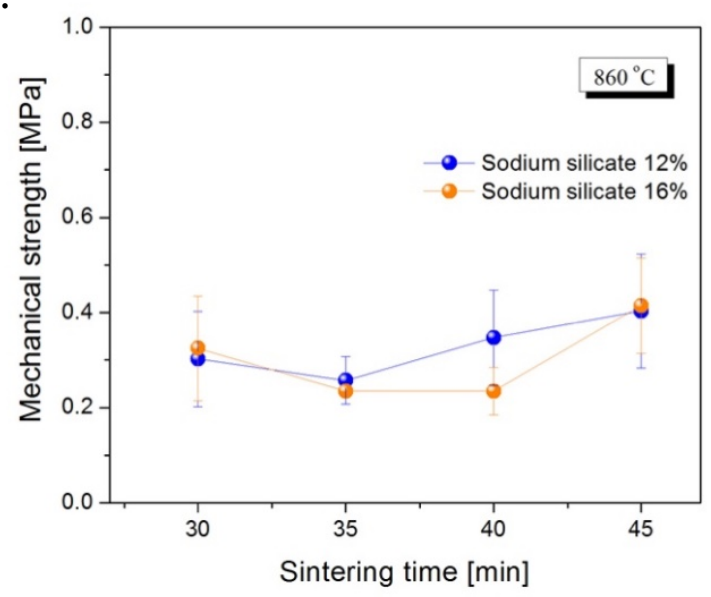

D.

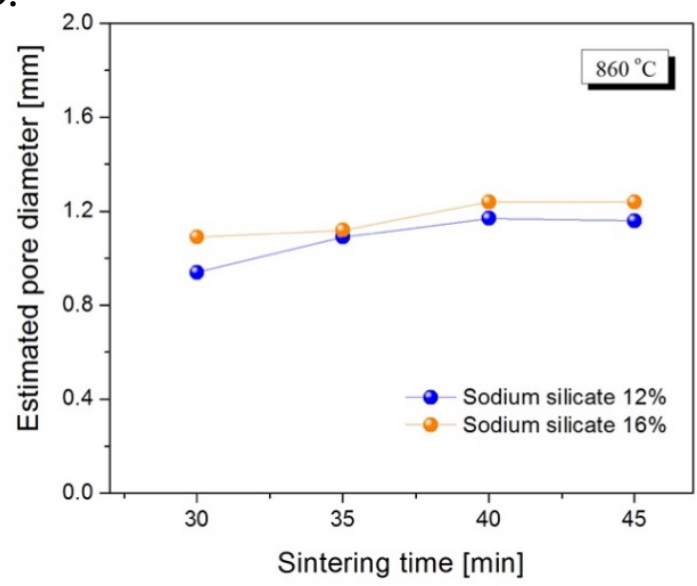

E.

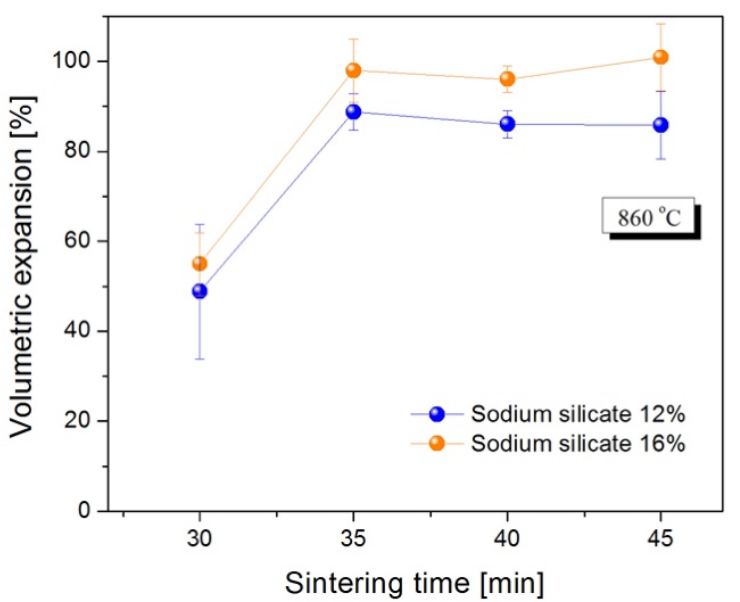

Figure 8. Effect of the sintering time in the characteristics of the ceramic foams obtained at $860{ }^{\circ} \mathrm{C}$ : apparent density (A), mechanical strength (B), porosity (C), pore diameter (D) and volumetric expansion (E).

On the other hand, Figure 8C-E show the effect of the change in sintering time on the apparent density, porosity, and average pore diameter of foams obtained at a fixed temperature of $860^{\circ} \mathrm{C}$. In the figures, it is possible to see that the increase in the sintering time did not generate a wide variation in the porosity developed by the samples, because they oscillated at values close to $80 \%$. However, it should be observed that the volumetric 
expansion and the average pore diameter are closely related to each other, since longer sintering times resulted in greater porosity, volumetric expansion, and pore diameter.

On the other hand, Figure 9 shows the cross-sections of the foams obtained at different sintering times and percentages of foaming agent of $12 \%$ and $16 \%$. In the figure, it is possible to observe that regardless of the percentage of foaming agent used and the different sintering times studied, there was a high porosity and a homogeneous distribution of pores along the entire surface. In addition, it was observed that a longer sintering time allowed a complete development of foam sintering when a sample was observed with a white coloration throughout the cross-section, independent of the percentage of foam used.

\begin{tabular}{|c|c|c|c|c|}
\hline \multirow{2}{*}{$\begin{array}{l}\text { Sodium } \\
\text { silicate } \\
\text { concentration }\end{array}$} & \multicolumn{4}{|c|}{ Sintering time } \\
\hline & $30 \mathrm{~min}$ & $35 \mathrm{~min}$ & $40 \mathrm{~min}$ & $45 \mathrm{~min}$ \\
\hline \multicolumn{5}{|l|}{$12 \%$} \\
\hline & $45 \mathrm{~mm}$ & $45 \mathrm{~mm}$ & $45 \mathrm{~mm}$ & $45 \mathrm{~mm}$ \\
\hline \multicolumn{5}{|l|}{$16 \%$} \\
\hline & $45 \mathrm{~mm}$ & $45 \mathrm{~mm}$ & $45 \mathrm{~mm}$ & $45 \mathrm{~mm}$ \\
\hline
\end{tabular}

Figure 9. Effect of the sintering time on the development of the porosity of the ceramic foams sintered at $860{ }^{\circ} \mathrm{C}$.

\subsection{Effect of Sintering Temperature on the Characteristics of the Foams}

Figure 10 shows the effect of the change in the sintering temperature on the apparent density and the mechanical strength of the foams obtained at a fixed sintering time of $45 \mathrm{~min}$.

Figure 10A shows that the apparent densities were found to be close to 0.5 ton $/ \mathrm{m}^{3}$, with the lowest density values obtained when a higher concentration of foam and the maximum sintering temperature were used. On the other hand, when analyzing the mechanical strength of the sintered samples at different sintering temperatures (Figure 10B), it is possible to note that the mechanical strength was between 0.1 and $0.4 \mathrm{MPa}$. The highest resistance to the lowest sintering temperatures was found, regardless of the percentage of foam used.

On the other hand, Figure 10C-E show the effect of the sintering temperature on the porosity, the average pore diameter, and the volumetric expansion of the foams obtained at a sintering time of $45 \mathrm{~min}$. In the figures, it is possible to observe that regardless of the percentage of foam used, an increase in the sintering temperature generated a high development of porosity, which was close to $80 \%$, without providing a wide variation in 
porosity when this temperature changed. However, it should be noted that the volumetric expansion and the average pore diameter showed an inverse behavior, i.e., a higher sintering temperature produced a contraction in the percentage of expansion and a greater porosity and pore diameter, resulting in expansion values between $150 \%$ and $46 \%$ and a maximum pore size of $1.8 \mathrm{~mm}$.

A.

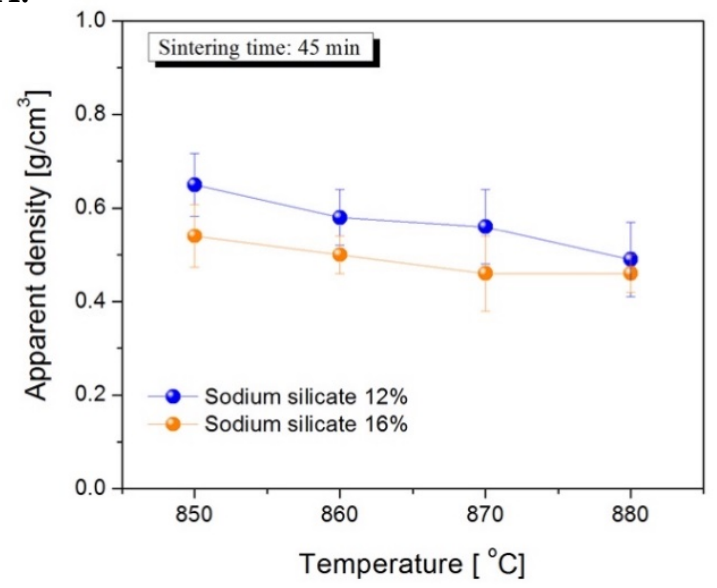

C.

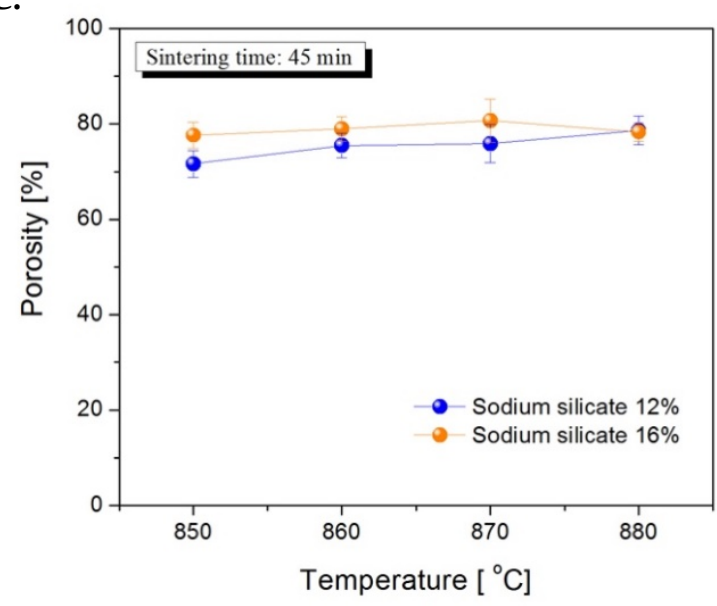

B.

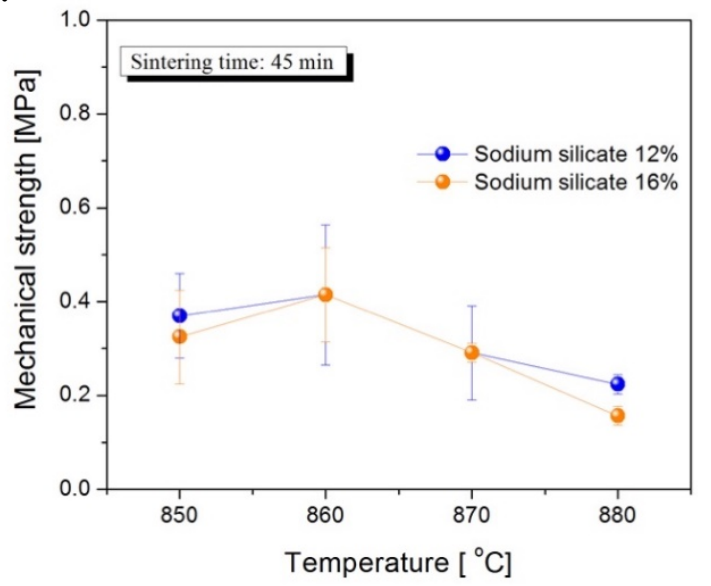

D.

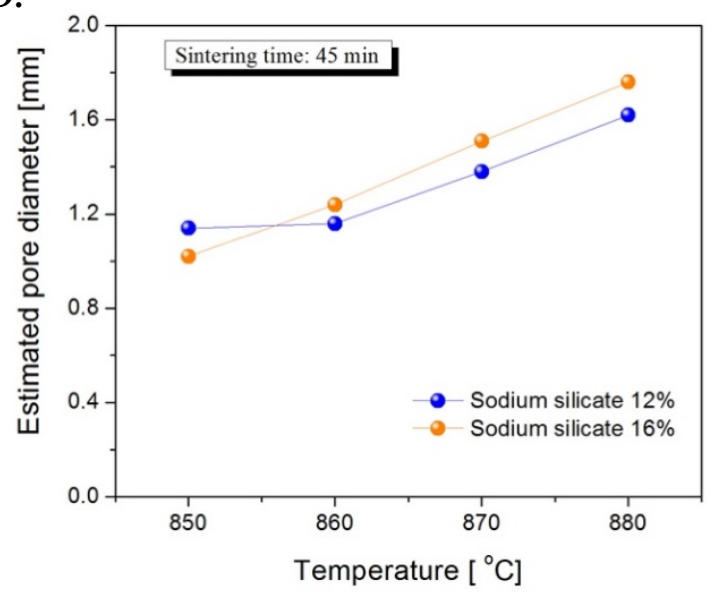

E.

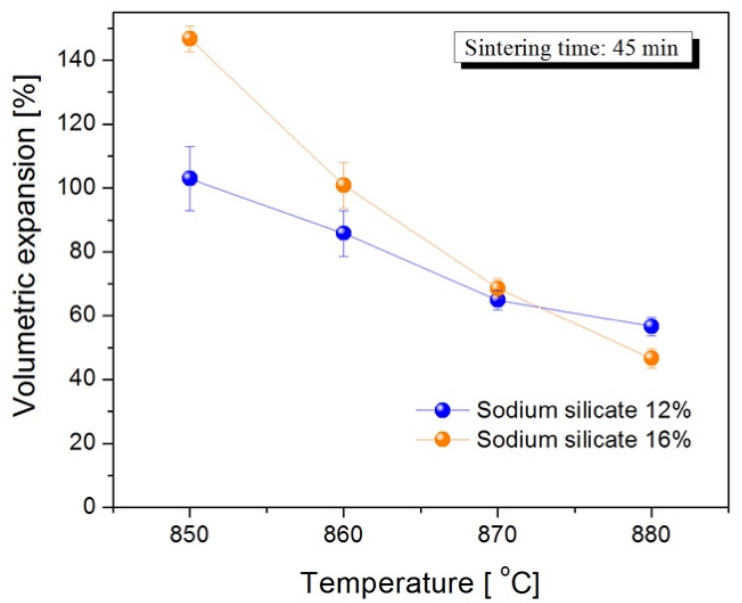

Figure 10. Effect of the sintering temperature on the characteristics of the ceramic foams obtained at a sintering time of 45 min: apparent density (A), mechanical strength (B), porosity (C), pore diameter (D) and volumetric expansion (E). 
Finally, Figure 11 shows the cross-sections of the foams obtained as a function of the sintering temperature using a foam percentage of $12 \%$ and $16 \%$. In the figure, it is possible to observe that in general, there was a homogeneous development of porosity throughout the cross-section of the samples. However, it should be noted that as the sintering temperature increased, larger and fewer pores were generated, as a result of the coalescence of the pores as the temperature increased, which occurred to a greater extent when $16 \%$ foaming agent was used.

\begin{tabular}{|c|c|c|c|c|}
\hline \multirow{2}{*}{$\begin{array}{c}\text { Sodium } \\
\text { silicate } \\
\text { concentration }\end{array}$} & \multicolumn{4}{|c|}{ Temperature } \\
\hline & $850^{\circ} \mathrm{C}$ & $860^{\circ} \mathrm{C}$ & $870^{\circ} \mathrm{C}$ & $880^{\circ} \mathrm{C}$ \\
\hline \multicolumn{5}{|l|}{$12 \%$} \\
\hline & $45 \mathrm{~mm}$ & $45 \mathrm{~mm}$ & $45 \mathrm{~mm}$ & $45 \mathrm{~mm}$ \\
\hline \multicolumn{5}{|l|}{$16 \%$} \\
\hline & $45 \mathrm{~mm}$ & $45 \mathrm{~mm}$ & $45 \mathrm{~mm}$ & $45 \mathrm{~mm}$ \\
\hline
\end{tabular}

Figure 11. Effect of the sintering temperature on the development of the porosity of the foams using a time of $45 \mathrm{~min}$.

\subsection{Crystalline Phase Analysis of Sintering Process}

Figure 12 shows the $\mathrm{X}$-ray diffractograms of a sample after the sintering process with $16 \mathrm{wt} \%$ sodium silicate and obtained at $860{ }^{\circ} \mathrm{C}$ for $45 \mathrm{~min}$. This sample was selected because it had the best results from the physical characterization (density, mechanical resistance, porosity, etc.). It can be observed that the sample was mainly composed of quartz (COD 9009666) and cristobalite (COD 9008226), this being a polymorph of silica that occurs at temperatures above $700{ }^{\circ} \mathrm{C}$. Calcium oxide (COD 9006568) and calcium silicate (COD 8103723) were generated by the transformation of the fluxing and foaming agents added during the stage of elaboration of foams and also are usually observed in devitrified soda-lime glasses. Finally, iron oxide (COD 9003076) is also present as part of the desulfurization process of the pyrite at temperatures above $500{ }^{\circ} \mathrm{C}$.

In addition, the crystalline phase percentage of $44.25 \%$ was determined using the HighScore Plus software (by measuring the area below the X-ray diffractogram/background). Therefore, it is possible to note a great formation of a vitreous phase as a product of the sintering process. 


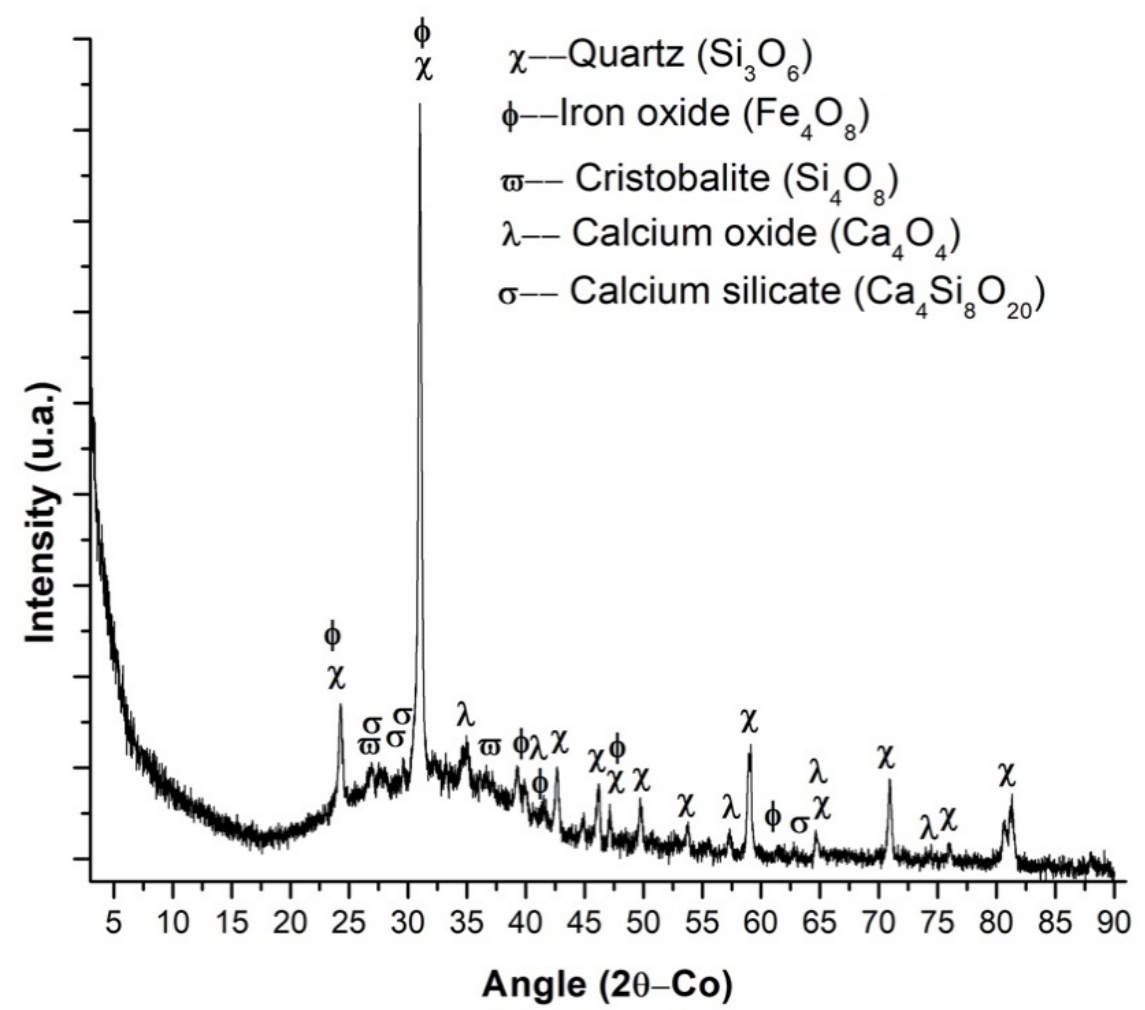

Figure 12. X-Ray diffractogram of a sample before and after the sintering process made with 16 wt $\%$ sodium silicate and obtained at $860^{\circ} \mathrm{C}$ for $45 \mathrm{~min}$.

\section{Discussion}

The physical properties obtained of tailing samples showed that the median size and $80 \%$ passing size were within the particle size recommended for the elaboration of ceramic foams, which should be lower than d50 100 microns and higher than d50 10 microns, in order to promote the low density of ceramic foams and avoid the drop in the viscosity during the foaming process [15].

Chemical and mineralogical characterization of the gold-silver tailing samples showed that this type of tailing presented an intermediate concentration of $\mathrm{SiO}_{2}$, which comes principally from the quartz phase $(55.06 \%)$, a minimum value of elements such as the alkali/alkaline earth metal oxides $\left(\mathrm{CaO}(0.19 \%)\right.$ and $\left.\mathrm{K}_{2} \mathrm{O}(1.35 \%)\right)$, alumina $\left(\mathrm{Al}_{2} \mathrm{O}_{3}(2.91 \%)\right)$, and a high concentration of sulfides associated mainly to pyrite $\left(\mathrm{FeS}_{2}, 34.57 \%\right)$. Comparing these results with the reported values from Liu et al. [11], the gold-silver tailing samples presented a high presence of pyrite $\left(\mathrm{FeS}_{2}, 34.57 \%\right)$. For this reason, a previous flotation process was required to increase the silicate content and eliminate the presence of this mineral composed of iron and sulfur.

The results obtained through the reverse flotation process showed that the presence of Fe and $\mathrm{S}$ associated with pyrite was eliminated to a great extent by showing a recovery and enrichment of these elements in the tail corresponding to $88.84 \%$ and $2.84 \%$ for Fe and $96.53 \%$ and $2.63 \%$ for sulfur, respectively. The above allowed obtaining a decrease in the grade of these elements in the concentrate of $8 \%(\mathrm{Fe})$ and $0.75 \%(\mathrm{~S})$. This indicates that the presence of $\mathrm{Fe}_{2} \mathrm{O}_{3}$ and $\mathrm{SO}_{3}$, which were associated mainly to pyrite, was reduced to $11.19 \%$ and $1.87 \%$, respectively. These values correspond to intermediate values of those reported in the literature regarding the elaboration of ceramic foams from tailings [13].

It is well known that the chemical and mineralogical composition of the raw materials have a direct influence on the characteristics of the ceramic foams. $\mathrm{SiO}_{2}$ and $\mathrm{Al}_{2} \mathrm{O}_{3}$ serve as network formers of glass and the main compositions of the ceramic framework. The alkaline oxides and alkaline earth oxides lower the sintering temperature and promote the liquid phase formation during the sintering process. In addition, it is well known that 
the oxidation of pyrite and the process of desulfuration contributed to the formation of the porous structure [11].

In relation to the previous statement and analyzing in the first place the foams made in the absence of a foaming agent, it could be observed that the presence of a low content of pyrite and alkaline oxides present in phases such as muscovite, chlorite, biotite, and $\mathrm{k}$-feldspar contributed to the sintering process and to generating the porous structure at higher temperatures and times of sintering. Studies carried out by Liu et al. $[9,11]$ show that there exist exothermic peaks at $475{ }^{\circ} \mathrm{C}$ and $712{ }^{\circ} \mathrm{C}$ attributed to the oxidation of pyrite and the desulfurization. This event generates gases, which are enclosed by the liquid phase to form the bubble nuclei and form the final porous structure. In addition, this development of porosity could also be associated with the presence of sodium silicate residues in the tailings, which are a product of its use to eliminate the presence of clay minerals during the recovery of different metals using the flotation process [16,17].

On the other hand, when analyzing the ceramic foams elaborated in the presence of different percentages of sodium silicate as a foaming agent, it could be observed that, independently of the percentage of foaming agent used, the sintering time, and temperature employed, the presence of the foaming agent contributed to a noticeable reduction in the apparent density and also to an increase of the porosity and the pore size, which affects directly the mechanical strength. In addition, the presence of foaming agent allowed achieving the best characteristics of the foams at lower sintering temperatures.

Finally, according to the operational conditions, the temperature had a greater influence on the characteristics of the ceramic foams than sintering time. This could be due to the fact that a sintering time of $45 \mathrm{~min}$ used to study the effect of temperature may have favored the depletion of network modifiers from the matrix and the diffusion of different ions $\left(\mathrm{Na}^{+}, \mathrm{Ca}^{2+}, \mathrm{Fe}^{2+}, \mathrm{K}^{+}\right.$, etc.) into the interior, resulting in a more homogenous distribution of these cations in the ceramic foams. In addition, the rapid liberation of the residual water from the hydrated silica molecules at higher temperatures $\left(>800^{\circ} \mathrm{C}\right) \mathrm{can}$ be the cause of the bigger pores obtained when temperature is increased, which generates a greater vapor pressure that provokes a more rapid pore expansion. Considering that the softening temperature of the $\mathrm{SiO}_{2}-\mathrm{CaO}-\mathrm{Na}_{2} \mathrm{CO}_{3}$ mixture is around $850-900{ }^{\circ} \mathrm{C}$ and the presence of pyrite in the tailings, the pore formation in the samples was mainly due to the dehydration reaction of the hydrated form of silica and also due to the oxidation of $\mathrm{FeS}_{2}$, according to the reaction indicated by [13].

According to the results obtained, it was possible to establish that the best characteristics of ceramic foams were obtained at temperatures between 850 and $860{ }^{\circ} \mathrm{C}$ and a sintering time of $45 \mathrm{~min}$. Under these conditions, a high volumetric expansion and porosity were obtained, with a uniform pore distribution, a mean pore size near $1 \mathrm{~mm}$, an apparent density between 0.65 and $0.50 \mathrm{~g} / \mathrm{cm}^{3}$, and a mechanical strength near $0.40 \mathrm{MPa}$.

\section{Conclusions}

The use of gold and silver tailings with a high content of pyrite to elaborate ceramic foams was possible, using a previous process of inverse flotation to reduce the presence of these minerals. However, the presence a low content of pyrite in the raw materials to elaborate the foams could contribute to the development of porosity due to the oxidation of these minerals.

In relation to the operational conditions, the temperature had a greater impact on the ceramic foams' properties due to linear trends in the material properties with the increase in sintering temperature in the range of values studied. In addition, the presence of alkali/alkaline earth metal oxides in the tailings and in the fluxing agents contributed to lowering the sintering temperature and promoted the liquid phase formation during the sintering process.

Finally, it was possible to observe that ceramic foams can be obtained with this type of tailing and absence of foaming agent, with a uniform pore distribution and values of apparent density and mechanical strength near $1.0 \mathrm{~g} / \mathrm{cm}^{3}$ and $0.5 \mathrm{MPa}$, respectively, 
when a higher sintering temperature and time were used. In addition, in the presence of foaming agent and the lower sintering temperatures, it was possible to obtain a uniform pore distribution and reduce the apparent density to $0.5 \mathrm{~g} / \mathrm{cm}^{3}$, without decreasing to a great extent the mechanical strength of ceramic foams.

Author Contributions: Data curation, investigation, software, validation, C.S.; conceptualization, methodology, visualization, formal analysis, investigation, writing-original draft preparation writingreview and editing, supervision, project administration, funding acquisition and resources validation, L.U. All authors have read and agreed to the published version of the manuscript.

Funding: This study was realized with funds granted by the project FIC-R 40008910-0, funds for Competitiveness of the Regional Government of O'Higgins in Chile.

Institutional Review Board Statement: Not applicable.

Informed Consent Statement: Not applicable.

Data Availability Statement: Not applicable.

Acknowledgments: The researchers acknowledge Minera Paicaví and Sernageomin for their support in this project and Cristina Cereceda for her technical support.

Conflicts of Interest: The authors declare no conflict of interest.

\section{References}

1. Edraki, M.; Baumgartl, T.; Manlapig, E.; Bradshaw, D.; Franks, D.M.; Moran, C.J. Designing mine tailings for better environmental, social and economic outcomes: A review of alternative approaches. J. Clean Prod. 2014, 84, 411-420. [CrossRef]

2. Berkh, K.; Rammlar, D.; Drobe, M.; Meima, J. Case Study: Geochemistry and Mineralogy of Copper Mine Tailings in Northern Central-Chile. In Proceedings of the 14th International Congress for Applied Mineralogy, Belgorod, Russia, 23-27 September 2019; pp. 37-40.

3. Park, I.; Baltazar, C.; Jeon, S.; Li, X.; Seno, K.; Ito, M. Hiroyoshi A review of recent strategies for acid mine drainage prevention and mine tailings recycling. Chemosphere 2019, 219, 588-606. [CrossRef] [PubMed]

4. Galvão, J.L.B.; Andrade, H.D.; Brigolini, G.J.; Peixoto, R.A.F.; Mendes, J.C. Reuse of iron ore tailings from tailings dams as pigment for sustainable paints. J. Clean. Prod. 2018, 20, 412-422. [CrossRef]

5. Argane, R.; Benzaazoua, M.; Hakkou, R.; Bouamrane, A. Reuse of base-metal tailings as aggregates for rendering mortars: Assessment of immobilization performances and environmental behavior. Constr. Build. Mater. 2015, 96, 296-306. [CrossRef]

6. Onuaguluchi, O.; Eren, O. Reusing copper tailings in concrete: Corrosion performance and socioeconomic implications for the Lefke-Xeros area of Cyprus. J. Clean. Prod. 2016, 112, 420-429. [CrossRef]

7. Scheffler, M.; Colombo, P. Cellular Ceramics: Structure, Manufacturing, Properties and Applications; WILEY-VCH Verlag GmbH \& Co. KGaA: Weinheim, Germany, 2006; Volume 645, pp. 33-176.

8. Zhang, S.; Kang, Z.; Lu, Q. Preparation of foam glass composite from iron ore tailing. Adv. Mater. Res. 2011, 168, 532-536. [CrossRef]

9. Liu, T.; Lin, C.; Liu, J.; Han, L.; Gui, H.; Li, C.; Zhou, X.; Tang, H.; Yang, Q.; Lu, A. Phase evolution, pore morphology and microstructure of glass ceramic foams derived from tailings wastes. Ceram. Int. 2018, 44, 14393-14400. [CrossRef]

10. Kazmina, O.V.; Tokareva, A.Y.; Vereshchagin, V.I. Using quartzofeldspathic waste to obtain foamed glass material. Resour. Technol. 2016, 2, 23-29. [CrossRef]

11. Liu, T.; Tang, Y.; Han, L.; Song, J.; Luo, Z.; Lu, A. Recycling of harmful waste lead-zinc mine tailings and fly ash for preparation of inorganic porous ceramics. Ceram. Int. 2017, 43, 4910-4918. [CrossRef]

12. Li, Z.; Luo, Z.; Li, X.; Liu, T.; Guan, L.; Wu, T.; Lu, A. Preparation and characterization of glass-ceramic foams with waste quartz sand and coal gangue in different proportions. J. Porous Mater. 2016, 23, 231-238. [CrossRef]

13. Uribe, L.; Moraga, C.; Rivas, F. Using gold-silver tailings on the elaboration of ceramic foams. J. Sustain. Metall. 2021, 7, 364-376. [CrossRef]

14. Uribe, L.; Giraldo, J.D.; Vargas, A. Effect of the Operational Conditions in the Characteristics of Ceramic Foams Obtained from Quartz and Sodium Silicate. Materials 2020, 13, 1806. [CrossRef] [PubMed]

15. König, J.; Petersen, R.; Yue, Y. Influence of the glass particle size on the foaming process and physical characteristicas of foam glasses. J. Non-Cryst. Solids 2016, 447, 190-197. [CrossRef]

16. Krishnan, S.V.; Iwasaki, I. Pulp dispersion in selective desliming of iron ores. Int. J. Miner. Process. 1984, 12, 1-13. [CrossRef]

17. Gan, W.; Liu, Q. Coagulation of bitumen with kaolinite in aqueous solutions containing $\mathrm{Ca}^{2+}, \mathrm{Mg}^{2+}$ and Fe $\mathrm{Fe}^{3+}$ : Effect of citric acid. J. Colloid Interface Sci. 2008, 324, 85-91. [CrossRef] [PubMed] 